\title{
Civil-Military Cooperation Professionals Training during the Military Education Reformation
}

\author{
Oksana Beryslavska \\ Military Law Department \\ Military institute of Taras Shevchenko \\ National University of Kyiv \\ Kyiv, Ukraine \\ http://orcid.org/0000-0002-8785-6623 \\ Volodymir Shulgin \\ Military Law Department \\ Military institute of Taras Shevchenko \\ National University of Kyiv \\ Kyiv, Ukraine \\ e-mail: vshulgin@ukr.net
}

\author{
Oleg Gushchyn \\ Military Law Department \\ Military institute of Taras Shevchenko \\ National University of Kyiv \\ Kyiv, Ukraine \\ http://orcid.org/ 0000-0003-2901-9605
}

\author{
Victor Dobrovolsky \\ Postgraduate Education Department \\ Military institute of Taras Shevchenko \\ National University of Kyiv \\ Kyiv, Ukraine \\ e-mail: bronislavovich@bigmir.net
}

\begin{abstract}
The article is devoted to the peculiarities of the structure and implementation of the Program for the training of specialists in civil-military cooperation in the system of higher military education, based on the use of a competence approach. The program provides the acquisition of general and professional competencies by professionals, including the expertise related to the application of an interdisciplinary approach. Such an approach is ensured by grouping disciplines according to their classification as a type of training, the correspondence of specialty and specialization, and combines the use of network educational technologies, the latest communicative teaching methods, the consideration of practical cases, etc.
\end{abstract}

As a result of the study it was determined that during the training of civil-military cooperation professionals special attention should be paid to linguistic and communicative competences, as well as special physical training. These competences are inherently general, but the use of an interdisciplinary approach and the structural and logical scheme for training, specified above, involves their integration into obtaining military special (professional) competencies.

The expediency of the introduction of special courses "Protection of Civilians in Armed Conflicts", "Public Administration in Armed Conflicts" as reflecting the implementation of the Comprehensive Approach concept is substantiated, which implies involving all branches of government, international and national non-governmental organizations, as well as civil society institutions to solving the problems associated with armed conflict.

It was stated that in the course of reforming both the system of higher education as a completely and higher military education in particular, there is a need for the training of professionally motivated military personnel in the field of civilmilitary relations. They should be able to communicate effectively and meet the needs of civilians in relation to the tasks of the armed forces. In this aspect, the Program of training specialists in the field of Civil-military Cooperation is relevant to the needs of society, and the position of CIMIC (Civil-military Cooperation) officer is a separate independent direction for the development of military careers.
Key words: competency approach, multidisciplinary approach, comprehensive approach, Civil-military cooperation, Civil-military cooperation training program.

\section{INTRODUCTION}

From 2014, a pilot civil-military cooperation project launched at the Ivan Cherniakhivsky National University of Defense has evolved into a powerful tool for ensuring the fulfillment of the main functions of the Armed Forces of Ukraine for its intended purpose.

From 1 September 2017, the General Staff of the Armed Forces of Ukraine launched training courses for civilmilitary cooperation specialists of the Armed Forces of Ukraine with a view to transition to the newly created military proficiency qualification 850400 "Civil-military cooperation" [1].

The management of the civil-military cooperation of the Armed Forces of Ukraine, including the overall leadership of the CIMIC units of the Armed Forces of Ukraine, planning, organization and control of the conduct of the CIMIC activities, is carried out by the Civil-military Cooperation Directorate of the Armed Forces of Ukraine [2].

Specialists of civil-military cooperation are planned to perform duties at positions in military administration bodies, military units, institutions, higher military educational institutions [1].

\section{THE AIM}

The purpose of the article is to study the training process of civil-military cooperation specialists in the context of higher military education reforming. The objectives of the article are to prove the feasibility of introducing the latest educational standards for the training of civil-military cooperation specialists using the competency approach, multidisciplinary approach, and to substantiate the necessity of developing special courses "Protection of Civilians in Armed Conflicts", "Public Administration in Armed Conflict" as they reflect the implementation of these approaches and the concept of Comprehensive approach. 


\section{MATERIALS AND METHODS}

The article used literature from various sources. In particular, the normative and legal acts on issues of civilmilitary cooperation (documents were downloaded from the following organizations' websites: NATO; Civil-military Cooperation of The Armed Forces of Ukraine).

The professional standard of an officer of the tactical level of the Armed Forces of Ukraine for military proficiency qualification $850400 \quad$ "Civil-military Cooperation" and the Educational and Professional Program "Civil-military Relations" were used as an example of the development and introduction of the latest educational standards for the training of Civil-military cooperation specialists. Statistics on civilian casualties related to the conflict in eastern Ukraine are also provided (documents were downloaded from the following organizations' websites: Office of the High Commissioner for Human Rights).

The doctrinal sources and practice of using the Comprehensive Approach concept in EU and NATO countries are analyzed in order to introduce such an approach to national conflict resolution and post-conflict settlement practice (documents were downloaded from the following organizations' websites: NATO; EU)

The main methods of research are comparative law for the analysis of normative acts and doctrinal sources from the problem under investigation, as well as the method of classification and grouping for the distribution of general and professional competencies of specialists in Civilmilitary cooperation and grouping disciplines according to the criterion of their attribution to the type of training, correspondence of the specialty and specialization.

\section{RESULTS}

According to S. Belay and D. Kornienko, the purpose and purpose of Civil-military cooperation is the interaction between military and civilian subjects within the framework of an integrated environment for maintaining the plan of the military command. The Civil-military cooperation units are the main commanders "advisers" and perform the following tasks: establish and maintain contact with civil actors at the appropriate level, promote cooperation, harmonization, exchange of information; define and explain the military objectives, tasks and concepts of the operation; promote parallel and integrated planning between military forces and friendly civilian actors; carry out integration with other types of personnel in all aspects of activity; constantly assess the operating environment, including local needs and inequality of opportunities for problem solving; carry out activities in the direction of timely and smooth transition of duties to the appropriate civil authority [3]

Analysis of acts regulating the activities of groups and joint centers of civil-military cooperation [4], [5] gives an opportunity to assert that the tasks of the teams and the CIMIC united centers in the JFO area can be grouped in the following directions: humanitarian assistance; infrastructure restoration; coordination of providing assistance to Ukrainian Armed Forces units by volunteers; evacuation of bodies of killed in action (including from temporarily occupied territory); media support; conducting lessons on mine safety [6].
We believe that specialists of civil-military cooperation of the Armed Forces of Ukraine, in addition to professional military skills, must have knowledge of the constitutional order of Ukraine, the functional responsibilities of representatives of all state power bodies, the rights and duties of representatives of various security structures, the foundations of criminal, civil, economic law, public administration and the order of functioning of all structural elements of local self-government bodies, as well as knowledge on psychology, conflict resolution and development and the ability to communicate with vulnerable segments of the population.

For this purpose, the Armed Forces Professional Standard of a tactical level officer for the military proficiency qualification 850400 "Civil-military Cooperation" [7] and the corresponding EducationalProfessional Program "Civil-military Relations" [8] were developed in cooperation with Armed Forces of Ukraine Civil-military Cooperation Directorate at the Military Institute of Taras Shevchenko Kyiv National University.

During the development of these documents, the author's team determined their need and potential. For this purpose, consultations were carried out with customers (potential employers), the issue of compliance of documents with new professional requirements was solved (I. Koropatnik, O. Gushchyn and other). The profile and key competencies of the program are also identified. For this purpose the basic disciplines / subject areas that form the basis of the educational program are defined; identified and described potential areas of activity for graduates to find employment; defined and described the contribution of the program for the development of personal and civic level of culture; identified key program competencies, which are divided into general and specific, most relevant to the proposed program (O. Beryslavska, O. Gushchyn, V. Shulgin and other). In addition, during the development of the program, the program results of the training were formulated, the educational program was modulated, the competences were determined and the learning outcomes for each module were formulated, approaches to teaching, training and assessment were defined; the coverage of key general and subjectspecific competencies by modules / units of the educational program was checked (O. Beryslavska, O. Gushchyn, I. Koropatnik, V. Shulgin and other).

These documents are based not only on a competent approach, which today has become a reality of modern education in its quest to meet European requirements, but also with the use of innovative approaches. According to I. Tolok and Y. Prikhodko, this will contribute to bringing the educational process in line with the experience of combat and operational training of forces, their application in peacekeeping operations, local conflicts, psychological and physiological capabilities of cadets; practical training of military specialists in training centers, military units according to the official appointment (specialty, qualification, peculiarities of the position) on active weapons and military equipment in conditions close to combat; application of personality-oriented technologies in the training of military personnel [9, p.266-267].

The educational-professional program "Civil-military relations" among the general competences of the military 
personnel determines the following: the ability to communicate in the state language both verbally and in writing, to have a good command of the legal terminology; the ability to communicate in a foreign language both orally and in writing, including in the professional field; the ability to apply knowledge in professional activities in normal and individual extraordinary situations; ability to plan and organize their professional activities. By their nature, they can be classified into disciplines that provide language and communicative competences and special physical training. Such disciplines include, in particular, "Ukrainian language (for professional orientation)", "Foreign language", "Foreign language in specialty", "Physical education and special physical training" [8]

The indicated competencies refer to the general, but the use of the interdisciplinary approach and the structural and logical scheme of training specialists in civil-military cooperation involves their integration into obtaining professional (military-specialized) competencies. For example, the ability to use military-specific terminology according to NATO standards. This competence is achieved by studying the following English language courses: "Intensive language course on the specifics of CIMIC (English)", "Training in the law of armed conflict", "CIMIC Reporting and Tracking System (CRTS)" [8].

The communicative competence of civil-military cooperation officers is exercised in the ability to organize and participate in negotiations between conflicting parties (the course "Conflict and Theory of Negotiations"), the ability to take measures to highlight the activities of the Armed Forces of Ukraine in the media, the ability to bring information material with critical priorities, solutions based on analytical data (course "Army and Media") [8]

We believe that communicative competence for civilmilitary cooperation is a key competence, and communication as a component of learning outcomes in discipline always involves an unambiguous understanding of the problem issue by a specialist, accurate statement of the findings and reporting of relevant information to the command and other parties to the process.

Taking into account the importance of special physical training for specialists of Civil-military cooperation, the training program provides for special courses "Use of force" and "Urban Defense Course". At the same time, for the courses of retraining and advanced training in the program Civil-military Cooperation provides the course "Armored Mental", which aims to prepare the human psyche for combat stress, prevent trauma during combat and gain practical skills to control stress in a critical situation, a life threatening. These courses developed according to NATO Allied Joint Doctrine for Civil-military Cooperation (STANAG 2509), NATO Military Policy on Civil-military Cooperation (CIMIC) and Civil-military Interaction (CMI), MC 0411/2, NATO Allied Joint Doctrine for Military Police (AJP-3.21), NATO Civil-military Cooperation Center of Excellence, CIMIC Handbook, Civil-military Cooperation and Military Police Interaction Status Report [10] - [14].

The Tactical Officer Professional Standard for military proficiency qualification $850400 \quad$ "Civil-military Cooperation" and the educational-professional program "Civil-military Relations" indicate the following professional (military-special) competencies: the ability to plan the use of CIMIC units during the training and conducting operations of the Armed Forces of Ukraine and to manage them ("Military and Political History of Ukraine", "International relations and national security in modern geopolitical conditions"; "Planning of application of CIMIC operations in the Armed Forces of Ukraine" courses); the ability to organize the commanders interaction with public authorities, civil society, non-governmental organizations, international organizations, media and civilians in the area of responsibility; the ability to organize measures for the restoration of critical infrastructure damaged during combat operations ("Military Administration in the direction of the Central Commander", "Public Administration in the Armed Conflict" courses); the ability to organize the evacuation of the population, assets and cultural objects from the areas of warfare; ability to command CIMIC units ("Protection of Civilians in Armed Conflict", "Joint Doctrine of Civil-military Cooperation" courses); the ability to collect, analyze information on the state of the civilian environment and formulate proposals to command the use of these analysis in the interests of the tasks of the Armed Forces of Ukraine for their intended purpose (courses: "Forecasting of information space", "CIMIC Reporting and Tracking System (CRTS)" [7], [8].

As we see, most of these competencies are of a managerial nature. We endorse the view that competency in managerial activity appears itself in the development of an officer of three fundamental qualities: a systemic vision of complex problems and a strategic approach to their solution; vision of prospects; the ability to adequately distribute the rights, responsibilities and responsibilities among the commanders of a military organization of any level so that the effectiveness of its operation is the highest. Continuing the opinion, L.Oliynyk notes that the competence of the officer's management is to make decisions in difficult situations, variants of which should be prepared with proper justification, reliable information support, comparative analysis with indication of risks and possible losses [15, p.218].

Thus, proceeding from the goal of legal education, which consists in the formation of the competences necessary for understanding the nature and functions of law, the content of the main legal institutions, the application of law, as well as legal regulation of various social relations, the system of training and retraining of Civil-military cooperation specialists of the Armed Forces of Ukraine, an interdisciplinary approach should be applied.

The effectiveness of such an approach is ensured by grouping disciplines according to their classification as training, the correspondence of specialty and specialization, the combination of the use of networked educational technologies, the latest communicative teaching methods, consideration of practical cases focused on general and professional competencies of CIMIC officers, in particular in the field of military and psychological training, as well as legal aspects of civil-military cooperation in the area of the Joint forces operation as well as peace and security operations [16].

O. Nozdrachev notes that in the western practice of civilmilitary relations, there is the concept of Comprehensive 
approach, which involves the involvement of all branches of government in solving problems. Primarily - in the social, economic, informational and military spheres [17].

The concept of Comprehensive Approach has become widespread, largely based on the experience of peacekeeping operations and crisis management. Such a concept is interesting for the study, since some experts have already put forward their arguments regarding the deployment of an international peacekeeping operation in the Donbass [18], [19], [20].

Under the heading "comprehensive approach to crisis management", the civil-military co-ordination (CMCO) called for a "culture of co-ordination", which was to permeate the entire crisis management cycle to allow for an efficient use of the EU's large civil-military toolbox. This comprehensive approach was and still is put in practice at the Horn of Africa, where joint civil-military CSDP efforts are carried out [21]

Nicoletta Pirozzi from Geneva Centre for Security Sector Governance in EU's Comprehensive Approach to Crisis Management, 2013, notes that the concept of a comprehensive approach to crisis management is not new for the EU, even though it has not been officially documented until this time. Such an approach can be considered as a political reaction to the evolution of the security concept beyond the conventional, state-centered, and militaristic terms of the bipolar era [22].

Mihai-Marcel Neag, Lucian Ispas and Cătălin Grindeanu in the Comprehensive Approach Concept in Multinational Operations, 2017, have determined that the concept of joint operations aimed at achieving a certain effect and an alternative to outdated national concepts is under the influence of transformations, so the process of planning joint operations is currently based on the concept of a comprehensive approach that is a strategic concept [23].

Finland also demonstrates its commitment to a comprehensive approach. Thus, the Good Practices of a Comprehensive Approach to Crisis Management, published in 2015 by The Finnish Center for Expertise in Comprehensive Crisis Management, states that among the challenges facing contemporary peacekeeping and crisis management, the theme of cooperation, coordination and engagement among them international actors, attracts a lot of attention. Comprehensive Approach, Common Governance Approach, Integrated Approach, Integrated Crisis Management, integrated crisis management - these are probably the most commonly used concepts - represent the various approaches by which international organizations (and some states contributing) are trying to increase the coherence of their participation and actions related to peacekeeping, peacekeeping and crisis management [24].

Faced with recurring complex crises requiring better coordination between civilian and military as well as with international and local actors, the concept of a comprehensive approach has emerged both in international organizations (NATO, EU etc.) and in governments (USA, France, United Kingdom etc.).

A comprehensive approach first provides for strengthened positions for the European Union and NATO, which have the potential of civilian and military crisis management and the desire for legitimacy. The approach analyzes the operational impact of an integrated approach for the military. Finally, it reinforces academic thinking about a comprehensive approach and introduces new topics for research in security research.

This approach has recently become important in the context of comprehensive stabilization operations, which are carried out primarily in Iraq and Afghanistan. Although this concept is experiencing "doctrinaire" and therefore remains blurred and inaccurate, it has revealed trends, in particular organizational and cultural changes [25].

Researchers from Sweden (Alicia Ohlsson, Claes Wallenius and Gerry Larsson) analyzed the possibilities of introducing a Comprehensive Approach in the Swedish armed forces and concluded, in particular, on the need to develop relevant competencies that are in line with the Leaderstone model based on the Comprehensive Approach. The UN, EU and NATO differ on how far they have developed Comprehensive Approach core conceptual documents, Sweden does not currently have a comprehensive approach of its own but seems to be headed in that direction. Small actors, such as Sweden, can mainly contribute to the larger actors with "plug-in" capabilities [26].

Based on foreign experience and taking into account the need for professional and effective management activities in the context of a continuing armed conflict and the subsequent post-conflict settlement, a special course "Public Administration in Armed Conflict" was developed. This course reflects the implementation of the Comprehensive Approach, i.e. involving all branches of government, international and national non-governmental organizations, as well as civil society institutions in addressing the problems of armed conflict. We believe that the key competence (military-special) competence in this discipline is the ability to manage, based on the use of modern concepts in the field of public administration built on the organization of interaction between government and society, taking into account the challenges and threats posed by armed conflict.

In addition, we support the idea that taking into account the experience of NATO countries, the promising goals are the training of specialists in Civil-military cooperation among not only military personnel, but also civilian personnel. Moreover, not only from the Armed Forces, but also from other interested departments ready to perform functions in the following areas: civil administration (public relations), namely specialists specializing in issues of public administration, law, education, medicine, issues safety and environmental protection; civilian infrastructure, namely specialists specializing in communications, transport, emergency response and occupational safety issues; humanitarian aid, namely specialists specializing in economic development, agriculture and food, industry and trade; cultural issues, namely, specialists who specialize in preserving architectural heritage, art, religion, and linguistic issues [27].

In particular, this proposal may be provided by the training of reserve officers for military proficiency qualification 850400 "Civil-military Cooperation" with the possibility of further staffing of the structures of civil- 
military cooperation in the Armed Forces of Ukraine.

Using this approach, a new special course "Protection of Civilians in Armed Conflicts" was developed. The need for the introduction of the course is because the statistics of violations of civil rights in connection with the conflict in the east of Ukraine is threatening. It updates the solution of this problem both at the international and national levels, including by studying the relevant rules of servicemen's treatment of civilians.

As indicated in the report of the Office of the United Nations High Commissioner for Human Rights on "Sexual Violence Related to the Conflict", in the five eastern regions of Ukraine affected by the conflict, 203 cases of sexual violence were identified, including 43 cases of rape after April 1, 2014. About $43 \%$ of victims of sexual violence are women between the ages of 25 and 36. Among these cases, $63 \%$ of them occurred outside the family, but it is difficult to determine how many of them are related to the conflict. In about $33 \%$ of cases, women could not identify their abusers. OHCHR observes that responding to conflictrelated sexual violence requires a comprehensive, crosssectoral approach that will include coordinated provision of medical services, protection, social and psychological support and access to justice for victims [28].

The report of the Office of the United Nations High Commissioner for Human Rights (OHCHR) "Human rights violations and abuses and international humanitarian law violations committed in the context of the Ilovaysk events in August 2014" indicate that victims of torture and illtreatment by the Ukrainian forces in Ilovaysk and its suburbs in August 2014 were men aged 30 to 66 who were suspected of being members of armed groups or in some way related to them. The cases documented and analyzed in this report by OHCHR indicate that during the fighting under Ilovaysk, all sides of the conflict have committed serious human rights violations, as well as violations of international humanitarian law, and some may be war crimes [29].

In the twenty-sixth report of the Office of the United Nations High Commissioner for Human Rights on the situation of human rights in Ukraine, it was stated that during the period from February 16 to May 15, 2019, 230 human rights violations that took place in the reporting period and victims of which 220 people In addition, during the reporting period, more than 198 violations that occurred before this reporting period were documented.

The total number of civilian deaths because of the conflict as of May 15, 2019 reached at least 3331 people.

In general, as of May 15, the average monthly civilian casualties in 2019 were 50 percent lower than in 2018, and one of the lowest in the entire period of the conflict. These figures show an opportunity to gradually reduce the number of civilian casualties to zero [30]

That is why we consider the course "Protection of Civilians in Armed Conflict" as an urgent need for gaining knowledge about the international legal concepts of the protection of civilians in armed conflicts, including the damage done to civilians, civilian objects, life support and infrastructure; violations of human rights in a conflict; use of civilians as living shields; the level of sexual / gender- based violence associated with the conflict and other problematic issues of the protection of civilians.

Among the key professional (military-specific) competencies in this discipline should be the ability to formulate proposals for compliance with the norms of international humanitarian law, rules of use of force in operations; ability to advise the civilian population to prevent civilian casualties [31].

In order to self-analyze the educational-professional program "Civil-Military Relations", a sample survey conducted through questionnaires (the questionnaire developed by O. Beryslavska using the materials of Y. Rashkevich's presentation [32]). Structurally, the questionnaire consists of three parts. The introductory part contains a response to the respondent, determined who conducted the questionnaire, how the results will be used, anonymity guaranteed, and the rules of the questionnaire explained. The main part contains research questions. This is the profile of the educational and professional program "Civil-Military Relations", the results of training under this program, the competency of the program. The third part of the questionnaire is demographic. It is, by its very nature, a set of questions regarding the status of a person and includes questions about age, education, position, academic degree / academic qualification, military service, years of service, participation in hostilities and level of foreign language proficiency. The survey conducted in 2018/2019 in three groups. The first group is the scientific and pedagogical staff of the Military Faculty of Finance and Law, who provide the teaching of disciplines in the Educational and professional Program "Civil-Military Relations" (group A - 25 people). The second group consists of scientific and pedagogical workers (military personnel) of the Military Institute, who teach general military disciplines (group B - 25 persons). The third group consists of scientific and pedagogical workers from among the civilians of the Law Faculty of Kyiv National Taras Shevchenko University (group $\mathrm{C}-25$ people).

Analysis of the processing of the questionnaires of scientific and pedagogical staff of the Military Faculty of Finance and Law, who provide the teaching of disciplines under the Educational and professional program "Civil-Military Relations" provides data on the status of respondents (group A): by gender: women $-36 \%$, men $-64 \%$; by age: from 25 to 40 years $-48 \%$, from 40 to 60 years $-40 \%$, over 60 years $-12 \%$; by education: complete higher education $-100 \%$, have a scientific degree $-84 \%$, have a scientific degree $-12 \%$; $100 \%$ of the interviewed persons hold scientific and pedagogical positions. Scientific and pedagogical experience of the respondents: $12 \%$ have more than 20 years, $56 \%$ from 10 to 20 years, and $32 \%$ from 5 to 10 years. Military ranks have $64 \%$ of respondents, $25 \%$ of them have over 20 years of service, $62.5 \%$ from 10 to 20 years, $12.5 \%$ from 5 to 10 years. The level of command of a foreign language confirmed by $64 \%$ of the respondents, $36 \%$ of the respondents participated in hostilities.

The analysis of the processing of the questionnaires of scientific-pedagogical staff (servicemen) of the Military Institute, teaching general military disciplines, provides data on the status of the interviewed persons (group B): by gender: women $-12 \%$, men $-88 \%$; by age: from 25 to 40 years $-40 \%$, from 40 to 60 years $-32 \%$, over 60 years $-28 \%$; by education: complete higher education $-100 \%$, have a scientific degree - 
$48 \%$, have a scientific degree $-4 \% ; 100 \%$ of the interviewed persons hold scientific and pedagogical positions. Scientific and pedagogical respondents: $12 \%$ have more than 20 years of experience, $48 \%$ from 10 to 20 years, and $40 \%$ from 5 to 10 years. Military ranks are $100 \%$ of those polled, $40 \%$ of them are over 20 years of service, $28 \%$ of those who are 10 to 20 years old, and $32 \%$ of those who are 5 to 10 years old. Foreign language proficiency was confirmed by $72 \%$ of respondents, and $44 \%$ of respondents participated in hostilities.

Analysis of the processing of questionnaires of scientific and pedagogical workers from among civilians of the Law Faculty of Taras Shevchenko National University of Kyiv (Fig.1) provides data on the status of interviewed persons (group C): by gender: women $-72 \%$, men $-28 \%$; by age: from 25 to 40 years $-48 \%$, from 40 to 60 years $-32 \%$, over 60 years $-20 \%$; by education: complete higher education $-100 \%$, have a scientific degree $-100 \%$, have a scientific degree $-84 \%$; $100 \%$ of respondents have scientific and pedagogical positions. Scientific and pedagogical experience of more than 20 years is $28 \%$, from 10 to 20 years $-24 \%$, from 5 to 10 years $-48 \%$. Foreign language proficiency confirmed by $40 \%$ of respondents, nobody did not participate in hostilities and have no military ranks.

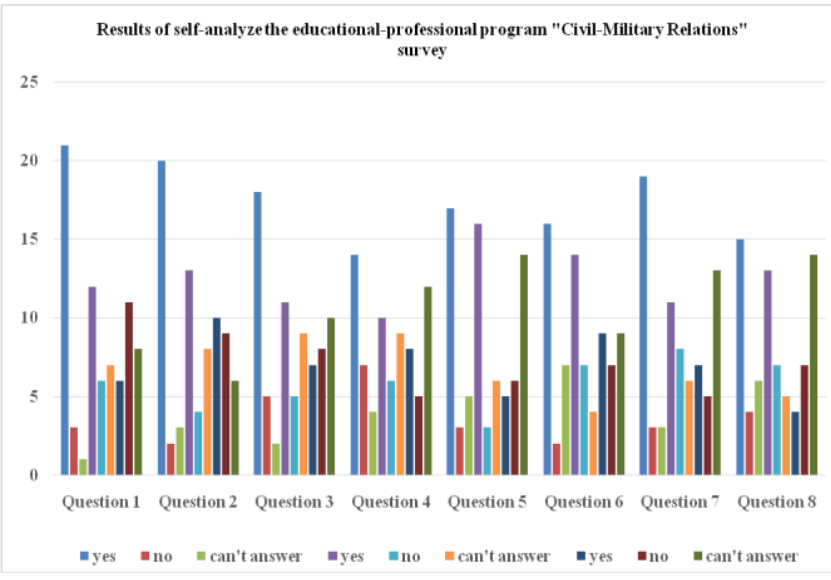

Fig. 1. Results of self-analysis the educational-professional program "Civil Military Relations" survay

From the chart below, we can conclude: persons with military rank, experience in engaging in hostilities (peacekeeping operations), a sufficient level of command of a foreign language consider the educational-professional program "Civil-Military Relations" to be progressive, balanced and also providing a consistent development of competences in the process of its realization; implementation of the educational-professional program "Civil-Military Relations" will promote the development of personal and civic level of culture of cadets/students/trainees, as well as enable scientific and pedagogical workers to use the most diverse, creative/innovative approaches to teaching and learning for the purpose of development as a general, and professional (military-special) competencies of the specialists of the specialty "Civil-military cooperation".

\section{CONCLUSION}

In the process of reforming both the system of higher education in general and higher military education, in particular, there is a need for training professionally motivated military personnel in the field of Civil-military relations capable of effective communication and ensuring the needs of the civilian population of Ukraine, taking into account the tasks of the armed forces. Thus, the Program of training specialists for Civil-military cooperation structures in the Armed Forces of Ukraine is complex and should take into account not only the challenges and threats in the course of the Joint forces operation, but also the practice of NATO in these aspects. That is precisely why we believe that the training of Civil-military cooperation military specialists is relevant to the needs of society, and the position of CIMIC officer should become a separate independent direction for the career development of servicemen.

\section{REFERENCES}

[1] MoD of Ukraine order № 43. (2017, January 23). Approval of the changes to the List of Military proficiency qualifications of officers, the List of military positions of officers who may be replaced by female servicemen, the List of Military proficiency qualifications for which the primary rank of junior lieutenant of the reserve may be given. [Online]. Available: https://zakon.rada.gov.ua/laws/show/z022 6-19. Accessed on: June 17, 2019.

[2] MoD of Ukraine order № 446. (2017, December 20). Regulation on CIMIC of the Armed Forces of Ukraine. [Online]. Available: https://cimic.com.ua/ Accessed on: June 17, 2019.

[3] S. Bielai, and D. Korniienko, "The role and place of units of civilmilitary cooperation in the settlement of armed conflict", in Scientificpractical conference "Service and combat activity of the National Guard of Ukraine: current state, problems and prospects",. Kharkiv, 2018, pp. 11-13.

[4] Order of the General Staff of the Armed Forces № 5. (2017, January 04). On Approval of the Procedure for Organizing the Preparation and Staffing of the Armed Forces of the Armed Forces Groups and Joint Centers for Civil-Military Cooperation Performing Tasks in the Area of Anti-Terrorism Operation in the Territory of Doenetz and Luhansk Oblasts. [Online]. Available: https://cimic.com.ua/. Accessed on: June 17, 2019.

[5] Order of the First Deputy Head of the Anti-Terrorist Center at the SBU (ATO Head) № 595oh. (2017, August 19). On Approval of the Regulations on Groups and Joint Centers for Civil-Military Cooperation Performing Tasks in the Area of Anti-Terrorism Operation in the Territory of Doenetz and Luhansk Oblasts. [Online]. Available: https://cimic.com.ua/. Accessed on: June 17, 2019.

[6] I. Koropatnik, and O. Beryslavska, "Legal Support for Civil-Military Cooperation", in Military Law, I.M. Koropatnik, and I.M. Shopina, Eds. Kyiv, Ukraine: Alerta, 1919, pp. 200-217.

[7] V. Kovalov at al., "Professional standard of tactical officer of the Armed Forces of Ukraine. Military proficiency qualification: 850400 Civil-military Cooperation". Branch of knowledge: 08 Law. Specialty: 081 Law. Kyiv, Ukraine, 2018.

[8] O. Beryslavska, I. Koropatnik, V. Shulgin, V. Pashynskyi, O. Gushchyn, and I. Kuzmenko, "Educational and Professional Program "Civil-Military Relations". Branch of knowledge: 08 Law. Specialty: 081 Law. Kyiv, Ukraine, 2018.

[9] I. Tolok, and Yu. Prykhodko, "Training military personnel with military education: innovative approaches", Pedagogical sciences: theory, page, innovative technologies. vol. 32, no. 6, pp. 259-269, 2013.

[10] NATO Allied Joint Doctrine for Civil-military Cooperation,STANAG 2509, EDITION 3, 9 November 2018, NSO (JOINT) 1381 (2018) AJOD/2509, 2018. [Online]. Available: https://nso.nato.int/nso/zPublic/stanags/CURRENT/2509EFed03.pdf. Accessed on: June 12, 2019.

[11] NATO Military Policy on Civil-military Cooperation (CIMIC) and Civil-military Interaction (CMI), MC 0411/2, 2014. [Online]. Available: https://www.cimic-coe.org/ccoe-news/north-atlanticcouncil-approves-cmi-and-cimic-policy/ Accessed on: June 12, 2019.

[12] NATO Allied Joint Doctrine for Military Police (AJP-3.21) EDITION A (STANAG 2296 Ed2), 2019. [Online]. Available: https://nso.nato.int/nso/nsdd/stanagdetails.html?idCover=9002. Accessed on: June 12, 2019. 
[13] W. van Koeveringe, Ed. "Civil-military Cooperation And Military Police Interaction Status Report", Hague, Netherlands: NLD Royal Marechaussee, CIMIC Centre of Excellence. 2016. [Online] Available: https://www.cimic-coe.org/wpcontent/uploads/2014/06/CIMIC-Military-Police-Interaction-StatusReport-CCOE-CD.pdf. Accessed on: June 12, 2019.

[14] CIMIC Handbook. Civil-military Cooperation Centre of Excellence, 2019. [Online]. Available: https://www.handbook.cimic-coe.org/ Accessed on: June 12, 2019.

[15] L. Oliinyk, "The competency of the modern officer as a result of professional education: a managerial aspect", Proceedings of the Military Institute of Taras Shevchenko National University of Kyiv, no. 55, pp. 216-221, 2017.

[16] O. Beryslavska, "Establishment of standards of training of specialists for the bodies of civil-military cooperation of the Armed Forces of Ukraine", in XIV International Scientific and Practical Conference "Military Education and Science: Present and Future". Kyiv, 2018, pp. 314-315.

[17] P. Khazan, "The CIMICs are helpers. How the military works with the locals in ATO", 2016. [Online]. Available: http://khazan.eu Accessed on: July 01, 2019.

[18] O. Kresin, I. Protsenko, K. Savchuk, and O. Stoiko, Political and Legal Foundations of the Donbass Peacekeeping Operation: A World Experience for Ukraine: Scientific note. Kyiv, Ukraine: V. Koretsky Institute of State and Law, National Academy of Sciences of Ukraine, 2018.

[19] Donbass War: The Realities and Prospects of Settlement: An Analytical Report, 2019. [Online]. Available: http://razumkov.org.ua/uploads/article/2019_Donbas.pdf. Accessed on: July 01, 2019.

[20] Models and Price of Donbass Conflict Resolution: International Experience and Ukrainian Realities. International Center for Policy Studies. $2016 . \quad$ [Online]. Available: http://icps.com.ua/assets/uploads/images/images/eu/donetsk.pdf. Accessed on: July 01, 2019.

[21] C. Moser, "Two Become One? On the Civil-Military Amalgamation of the CSDP", VerfBlog, no. 3, Mar. 30, 2019. [Online]. Available: https://verfassungsblog.de/two-become-one-on-the-civil-militaryamalgamation-of-the-csdp/, DOI: https://doi.org/10.17176/20190517144329-0. Accessed on: June 09, 2019.

[22] N. Pirozzi, "EU's Comrehensive Approach to Crisis Management". Brussels, Belgium: DCAF, 2013. [Online]. Available: https://www.dcaf.ch/sites/default/files/publications/documents/Pirozzi _EU-CM.PDF. Accessed on: June 09, 2019.

[23] M.M. Neag, L. Ispas, and C. Grindeanu, "The comprehensive approach Concept in Multinational Operations", Revista Academiei Forţelor Terestre. vol. 88, no. 4, pp.220-226, 2017. [Online]. Available:http://www.armyacademy.ro/reviste/rev4_2017/NEAG.pdf. Accessed on: June 09, 2019.
[24] J. Mustonen, Ed "Good Practices of a Comprehensive Approach to Crisis Management", Helsinki, Finland: The Finnish Centre of Expertise in Comprehensive Crisis Management: The Finnish Defence Forces International Centre and Crisis Management Centre Finland, 2015. [Online]. Available: https://puolustusvoimat.fi/documents/1951249/2094941/FINCENTPublication-2015-20162202.pdf/b9dc3163-ab68-4e6c-978fb1503f036121/FINCENT-Publication-2015-20162202.pdf.pdf Accessed on: June 09, 2019.

[25] C. Wendling, "The Comprehensive Approach to Civil-military Crisis Management: A Critical Analysis and Perspective". Irsem, 2010. [Online]. Available: https://www.eisf.eu/wpcontent/uploads/2014/09/0155-Wendling-2010-Comprehensiveapproach.pdf. Accessed on: June 09, 2019.

[26] A. Ohlsson, C. Wallenius, and G. Larsson, "The Comprehensive Approach - Doctrinal Overview and Swedish Leadership Implications at the Operative and Tactical Level", Journal of International Peacekeeping, vol. 18, no. 3-4, 2014. [Online]. Available: $\quad$ https://brill.com/view/journals/joup/18/3-4/articlep318_11.xml. DOI: https://doi.org/10.1163/18754112-1804011. Accessed on: June 09, 2019.

[27] I. Koropatnik, Interaction between civil society and the Armed Forces of Ukraine: administrative and legal framework. Kyiv, Ukraine: "MP Lesia", 2016.

[28] Conflict-Related Sexual Violence in Ukraine 14 March 2014 to 31 January 2017. Office of the United Nations High Commissioner for Human Rights, 2017. [Online]. Available: https://www.ohchr.org/Documents/Countries/UA/ReportCRSV_EN.p df?fbclid=IwAR1779gKaQW2ktUzdtq4U4tx0UKrY69D-. riklFDWVBnVap0KLmkInGvuIg. Accessed on: June 12, 2019.

[29] Human rights violations and abuses and international humanitarian law violations committed in the context of the Ilovaisk events in August 2014. Office of the United Nations High Commissioner for Human Rights, 2018. [Online]. Available: https://www.ohchr.org/Documents/Countries/UA/ReportOnIlovaisk_ EN.pdf. Accessed on: June 12, 2019.

[30] Report on the human rights situation in Ukraine 16 February to 15 May 2019. Office of the United Nations High Commissioner for Human Rights, 2019. [Online]. Available: https://www.ohchr.org/Documents/Countries/UA/ReportUkraine16Fe b-15May2019_EN.pdf. Accessed on: June 12, 2019.

[31] O. Gushchyn, and O. Beryslavska, "Working program of the discipline "Protection of civilians in armed conflict". Branch of knowledge: 08 Law. Specialty: 081 Law. Kyiv, Ukraine, 2019.

[32] Yu. Rashkevich, "Proceedings of the national team of experts on higher education reform, "NEO in Ukraine" EU project", 2015. [Online]. Available: http://www.erasmusplus.org.ua/erasmus/ka3pidtrymka-reform/natsionalna-komanda-ekspertiv-here/materialihere.html. Accessed on: July 04, 2019 